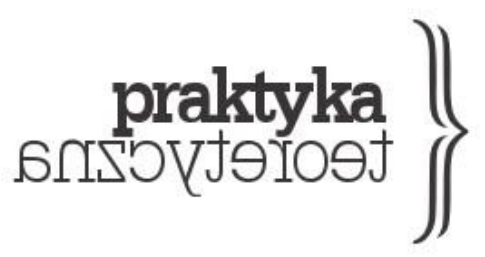

ISSN 2081-8130

DOI: $10.14746 /$ prt.2018.2.10 www.praktykateoretyczna.pl

\title{
NOWE FORMY KAMPU, NOWA KLASA KREATYWNA I WYNIKAJĄCE STĄD NIEPOROZUMIENIA
}

\section{PIOTR SOBOLCZYK}

\begin{abstract}
Abstrakt: Autor tekstu stawia pytania, jak zmienia się relacja współczesnej polskiej kultury gejowskiej do kampu oraz jaka wskutek tych przemian jest relacja kampu do nowych zjawisk popkulturowych. Nadto autor rozważa, czy w odniesieniu do (kampowej) wspólnoty smaku i stylu życia można mówić o „nowej klasie kreatywnej” w rozumieniu Richarda Floridy. Dyskutowane sa tu zjawiska takie jak ,gejowskie diwy”, „,winne przyjemności” (guilty pleasures), „beka” oraz „hipsteria”. Materiał pochodzi z polskiej prasy LGBTQ.
\end{abstract}

Słowa kluczowe: kamp, kultura gejowska, nowa klasa kreatywna, prasa LGBTQ, pop. 


\section{Wprowadzenie: nowe formy kampu - nowa klasa kreatywna?}

W niniejszym tekście rozważam kilka nowych zjawisk w kulturze bądź kilka nowych postaci fenomenów kulturowych, znanych dawniej w aspekcie ich związków z kampem, formą czy stylem kultury o długiej tradycji, choć w Polsce szerzej opisywanym dopiero od około dwudziestu lat. Wyliczę te zjawiska pokrewne w takiej kolejności, w jakiej będą następnie przybliżane: kult „gejowskich diw”, popkultura postmodernistyczna (a w kontekście polskim - potransformacyjna), „winne zabawy” (guilty pleasures), „beka”, hipsteria. Materiał wyjściowy stanowi dla mnie numer tematyczny gejowskiego magazynu lifestyle'owego Pride, poświęcony kampowi ujmowanemu nie w sposób akademicki, choć pojęcie to, jak wskazuję w początkowych analizach, jest przez redakcję maskowane, zapewne nie przypadkiem; zawartość tego numeru jest natomiast punktem wyjścia do poszerzonych analiz kulturowych i dyskusji nad miejscem kampu we współczesnej polskiej kulturze LGBTQ.

Te nowe formy kultury niejednokrotnie wykraczaja poza dotychczas znane postaci kampu, a jednocześnie sam kamp nieustannie się zmienia, przez co teoretycy powattpiewaja w możliwość zdefiniowania go. Zasadne staje się tedy pytanie o możliwość poszerzenia kategorii kamp, bądź też obrona odrębności tejże kategorii. Skoro kampu nie da się zdefiniować, jest „w oku patrzącego” (Ross 2012, 336) i nieustannie się zmienia, można by argumentować, że obstawanie choćby przy zrębach quasi-definicji tego zjawiska jest sprzeczne z samą idea kampu. Problem ten chciałbym przeformułować, stawiając pytanie, komu potrzebna jest quasi-definicja kampu, wydobywająca jego dystynktywność względem innych zjawisk kultury. Otóż zupełnie nie jest ona potrzebna „kamperom” - tak określam „podmioty kampu” (czy „podmioty kampowe”, choć to nie zawsze to samo) - praktykom czy performerom tego stylu. Jak zwracałem uwage w innych tekstach, z historycznego punktu widzenia podmioty homoseksualne i ich rozumiejący przyjaciele (najczęściej przyjaciółki) angażowały się w praktyki kampowe prawem pana Jourdain, nie wiedząc, że istnieje takie pojęcie. Dotyczyło to w szczególności krajów Europy Środkowej w czasach realnego socjalizmu, ale także, jak sądzę, kultur pozaeuropejskich. W kampie istotne jest nie samo słowo, pojęcie, ale pewna przestrzeń uprawiania alternatywy, ekspresji nienormatywnej, kulturowo zróżnicowanej (Sobolczyk 2015, 399-400). Także współcześnie forma ekspresji oferująca komfort i zarazem komizm, adekwatnie opozycyjna wobec obowiązującej „normy”, znajdzie sobie niszę, właściwa sobie przestrzeń, ściślej zaś - znajda ją „kamperzy”, którzy mało troszczą się o to, czy jakakolwiek definicja z przeszłości przystaje do owej przestrzeni.

Inaczej natomiast wygląda sprawa z kampem jako teorią akademicką; przypomnijmy, że Susan Sontag uznała ją, bez watpienia słusznie, za „zdradę” prawdziwego kampu (2012, 49). Choć z perspektywy akademickiej może się to wydawać zdumiewające, kamp jest przede 
wszystkim praktyką, a nie jej opisami. Mimo że wielu badaczy kampu podkreśla bądź milcząco zakłada, że kampu nie da się zdefiniować, można tylko oferować jego mniej lub bardziej chimeryczne opisy, to jednak z dyskursywnej konieczności muszą oni posługiwać się jakąś quasi-definicją kampu. I w takim właśnie heurystycznym sensie próba zarysowania nieciagłych i dyskusyjnych czy negocjowalnych granic kategorii kamp może okazać się sensowna. Jeśli więc w kolejnych partiach tekstu będę zwracał uwagę, że dane zjawisko nie jest kampowe, będzie to wypadkowa mojego wyczucia jako „kampera” i zarazem badacza kampu, który zna dyskursy; tak postępują zresztą wszyscy badacze kampu', jest tu nieusuwalna doza arbitralności ocen. Zasadniczą właściwością kampu, której chciałbym „bronič przed rozmywaniem jej linii demarkacyjnych, jest „mniejszościowość”. Nie seksualna, ale mniejszościowość stylu, smaku bądź sposobu odbioru - gdy rzecz dotyczy mainstreamowego zjawiska kulturowego.

$\mathrm{Na}$ ten problem można jednak spojrzeć jeszcze z innej strony, łaskawiej odnosząc się do zacierania dystynktywności „prawdziwego kampu”. Chodziłoby o udział kampu w formowaniu się nowej postaci kultury związanej z (nowa) „klasą kreatywną, którą opisuje Richard Florida. Wskażę tylko kilka wątków z badań Floridy, które wydają mi się istotne dla opisu zmieniającej się obecności kampu czy jego odczuwania w kulturze najnowszej. Florida podkreśla, że wraz z ekspansją klasy kreatywnej zatarła się opozycja bourgeois/bohemian, tak ważna dla etosu modernizmu, w zakresie świata pracy zaś istotna dla tzw. organisation man, człowieka korporacji lub urzędnika przeciwstawianego artyście czy środowisku „cyganerii” (Florida 2010, 197-218). Klasa kreatywna to ludzie „BoBo”2 - bohemian \& bourgeois, łączący w stylu bycia i stylu pracy wartości obydwu tych etosów, co alegorycznie ilustruje obraz nowego pracownika, ubierającego się do pracy swobodnie, np. w strój punka, pracującego w czasie nienormowanym i nie tylko w biurze, a jednak pracującego bardzo dużo i posiadającego znakomite wyniki. Otóż historycznie rzecz biorąc, kamp wyraźnie sytuował się na skrzydle bohemian, a jednak nie był tylko właściwością „bohemy”: był to styl uprawiany pokatnie, „w szafie”, to znaczy w barach, na prywatnych imprezach, kiedy to zarówno artyści czy ludzie żyjący jako „bohema”, jak i ludzie na co dzień i oficjalnie żyjący jako „burżuazja” łączyli się i mieszali w absurdalnych small talkach czy innych performansach. Zarówno dla „bohemy”, jak i dla luzującej po godzinach ciasny kołnierzyk „burżuazji” było wówczas

\footnotetext{
${ }^{1}$ Szczególnie ci, którzy tworzą listy bądź słowniki tego, co „kampowe”. Np. Sontag (2012), Core (1984).

2 Por.: ,The grand achievement of the educated elites in the 1990s was to create a way o living that lets you be an affluent success and at the same time a free-spirit rebel. [...] When you are amidst the educated upscalers, you can never be sure if you're living in a world of hippies or stockbrokers. In reality you have entered the hybrid world in which everybody is a little of both. [...] The values of the bourgeois mainstream culture and the values of the 1960s counter-culture have merged. That culture war has ended, at least within the educated class. In its place that class has created a third culture, which is a reconciliation between the previous two. [...] it is impossible to tell who co-opted whom, because in reality the bohemians and the bourgeois co-opted each other. They emerge from this process as bourgeois bohemians, or Bobos” (Brooks 2001, 42-43).
} 
jednak jasne, że te praktyki są mniejszościowe; że stanowią przestrzeń „alternatywy”3. Jeżeli zaś nie chodziło o performowanie siebie, ale o odbiór artefaktów kultury, także tych mainstreamowych, to również był to odbiór „mniejszościowy”, wbrew szeroko uznawanym kodom odbioru. Jeśli przyjąć za twórca pojęcia „Bobo” Davidem Brooksem, a także np. za Tomem Frankiem, że współczesna synteza czy big morph (jak mówi Florida) obydwu „bo-” jest skutkiem asymilacji wartości kontrkultury lat sześćdziesiątych, to zapewne jedną z tych wartości okaże się także kamp, który właśnie w latach sześćdziesiątych został dostrzeżony i przechwycony przez elity bohemy i kontrkultury, to znaczy przesunął się z ",marginesu marginesów” (gejowskich barów) do „centrum marginesu”, jakim wówczas była kontrkultura (Sontag pioniersko opisała to znacznie starsze zjawisko na łamach lewicowego, a wydawanego na kampusie Rutgers University Partisan Review w 1964).

Jeżeli - jak pisze Florida - w mainstreamie „klasy kreatywnej”, który nie pokrywa się z „mainstreamem” całego społeczeństwa, etos „bohemy” przesunął się w stronę centrum i pozwolił na swobodną ekspresje nie tylko artystom, a ekspresja jest pojmowana jako wzbogacająca doświadczenie zawodowe (Florida 2010, 106 i 198) - to ostatnie bowiem zostaje zdefiniowane jako „kreatywność”, a nie tylko „wykonywanie zadań” - to wówczas dawny kamp staje się jednym z dostępnych stylów ekspresji alternatywnej, łączącym się $z$ innymi stylami offowymi ${ }^{4}$. Florida wskazuje wszak, że gust klasy kreatywnej zwykle zorientowany jest na nieinstytucjonalne, offowe zjawiska kultury, a więc raczej na, załóżmy, uliczny festiwal kapel garażowych niż na symfonię w filharmonii (i nie idzie tu o proste odrzucenie etosu „kultury wysokiej” na rzecz „popu”, ponieważ ten podział został rozmyty) (Florida 2010, 268-269). Pojmowanie offu zmienia się w podobny sposób jak kategoria kampu - gdy coś przesuwa się w kierunku mainstreamu, poszukiwane są nowe zjawiska dalekie od mainstreamu. W tym sensie mechanizm kampu może wydawać się podobny do mechanizmu „hipsterii”, o czym piszę w dalszej części artykułu. Florida powołuje się na badaczy zjawiska commodificaton of cool, czyli prób przechwytywania zjawisk mniejszościowych, offowych przez mainstream, który reprezentuja instytucje ekonomiczne

\footnotetext{
3 Taki też, jak sądzę, jest wydźwięk dwóch „reguł kampu” zaproponowanych przez Philipa Core’a: „KAMP kiedyś był więzieniem dla nielegalnej mniejszości; dziś to wakacje dla dorosłych, którzy wiedzą, co robią. KAMP jest, po pierwsze, drugim dzieciństwem" (Core 2012, 392). Warto tu zwrócić uwagę na trudne do przetłumaczenia wyrażenie holiday for consenting adults (Core 1984, 7). Otóż właśnie bycie bohemian stanowiło rodzaj „wakacji” dla osób pracujących poza sztuką. Florida mówi o zmianie paradygmatycznej, w ramach której dostrzeżono, że elementy tożsamości wcześniej postrzegane jako „prywatne”, dla jednych kamp, dla innych jakieś tzw. hobby, wraz z przejściem ku kulturze „ekspresji własnej twórczej tożsamości” przestały być uznawane za ciekawe tylko poza kontekstem pracy, a uznano je za potencjalnie wzbogacające aktywność zawodowa. Ponieważ kampowe small talki bywają niezwykle błyskotliwe i konceptystyczne, nie sposób nie uznać, że mogą one wzbogacić wszelką aktywność zawodową opartą na komunikacji - najoczywistszym przykładem wydaje się copyrighting. A można sobie wyobrazić także i mniej oczywiste wpływy.

4 W ósmej notatce Sontag używa pojęcia the „off”, co Wertenstein tłumaczy następująco: „Jest to miłość do tego, co przesadne, co »się nie mieści« [off]” (Sontag 2012, 53).
} 
przestarzałego typu, to znaczy „starego” kapitalizmu neoliberalnego. Idzie tu o problem „sprzedawania się twórcy niezależnego”. Takie postawienie sprawy oparte jest jednak na rozdziale bohemian od bourgeois ${ }^{5}$. Jak twierdzi Florida, klasa kreatywna patrzy na takie zjawiska dużo bardziej „,horyzontalnie” i „sieciowo”, to znaczy nie w oparciu o hierarchiczne struktury, ale z nastawieniem na współpracę niezależnie od tzw. pozycji ${ }^{6}$. Ze względu na koegzystencję mitu „modernistycznego”, elitarystycznego (podkreślającego opozycję niezależności ujmowanej jako autentyczność i utowarowienia rozumianego jako „zła kopia”) z horyzontalno-sieciowym pojmowaniem kultury i jej relacji z biznesem zarówno twórcy, jak i odbiorcy oraz pośrednicy (w tym krytyka artystyczna i akademia) moga dowolnie odwoływać się do obydwu ujęć, a to skutkuje różnorodnymi, niekiedy wręcz wewnętrznie sprzecznymi formułami w dyskursie na temat kultury współczesnej.

Wreszcie, Florida mocno podkreśla etos tolerancji, mierzony Wskaźnikiem Liczby Gejów (Gay Index), jako jeden z filarów nowej „klasy kreatywnej” (Florida 2010, 263-267). Konkluzja istotna dla moich rozważań jest taka, że gejowska ekspresja nie jest już, inaczej niż w przeszłości, krytycznie oceniana w środowisku zawodowym czy po prostu innym niż „bohema”, tym samym kamp w dotychczasowej postaci jest „mile widziany”. Przyjąwszy takie założenia, można uznać, że tradycyjne postaci kampowej ekspresji przesunęły się w stronę centrum i wymieszały z innymi stylami uprzednio alternatywnymi, stając się dostępnymi stylami ekspresji - co nie znaczy, że „kamp mniejszościowy” w nowym duchu, który ktoś mógłby określić jako „prawdziwy kamp”, musiał zaniknąć. To rzekłszy, należy postawić pytanie, na ile owe przemiany kulturowe w Stanach Zjednoczonych i być może innych krajach Zachodu, widoczne z Polski w dobie globalizacji, maja rzeczywisty wpływ na kulturę polską oraz miejsce, jakie zajmuje w niej kamp. Pytanie to powróci w zakończeniu.

\section{Miejsce kampu w gejowskiej kulturze konsumpcyjnej}

Czwarty numer gejowskiego czasopisma Pride. Magazyn swiadomych mężçyznn poświęcony jest zjawiskom kampu i kiczu, choć informacja ta została nieco ukryta: nie pojawia się na okładce

\footnotetext{
${ }^{5}$ Inni badacze (Chris Gibson i Lily Kong) zwracają uwagę, że nie był to przepływ tylko jednokierunkowy dokonuje się utowarowienie kultury, ale też wpisanie treści symbolicznych w produkcję towarową. Dlatego właśnie można zaobserwować wzrost (zapotrzebowania na) kreatywność(i). Tę tezę podaję za: Wojnar 2016, 19.

6 Por.: „And from its very beginnings down to the present, business dogged the counterculture with a fake counterculture, a commercial replica that seemed to ape its every move for the titillation of the TV-watching millions and the nation's corporate sponsors” (Frank 1997, 7). Frank zwraca uwage, że mit „niezależności” był oparty na przeświadczeniu, iż kontrkultura jest z zasady antykapitalistyczna, które to przekonanie podzielali zarówno konserwatyści, jak i nowa lewica oraz sama bohema. Tymczasem z perspektywy czasu, twierdzi Frank, można uznać, że kontrkultura była wpisana w logikę kapitalizmu. Skądinąd już w połowie lat pięćdziesiątych stwierdzał to Herbert Marcuse.
} 
ani w spisie treści, nie ma o niej mowy także we wstępniaku; jednak już po pobieżnym przejrzeniu zawartości kwartalnika cognoscenti zrekonstruuja „klucz tematyczny”. Zresztą w niektórych wywiadach i tekstach autorzy zdradzili się, że taka wytyczna programowa została im zasugerowana7. Być może wyciaganie wniosków na temat ukrytych znaczeń takiego gestu wyda się przesadą - dlaczego jednak unikać przesady w pisaniu o kampie, to znaczy w „prawdziwym” pisaniu o „prawdziwym” kampie? Na etapie „okładkowym” redakcja prawdopodobnie uznała, że epatowanie słownikiem intelektualnym w numerze publikowanym latem zadziała na czytelników odstraszająco. „Zamiast” kampu mamy więc na okładce Dodę i jej propozycję, by rodacy wyluzowali. Podkreślam: „zamiast”, choć pewnie znaleźliby się czytelnicy, którzy uznaliby, że nie „zamiast”, a „w charakterze ilustracji”.

Hipostaza globalnego narratora numeru mówiącego o kampie wpisuje się w szerszą strategię narracyjną Pride: jest to przewodnik i doradca, a tylko czasami „nauczyciel” (i to taki pogrywający resentymentem - co zrobić, aby dostać dobra ocenę i tym samym zostać zaliczonym w poczet elity), który wskazuje, „co zaliczyć, żeby się liczyć?”, by sparafrazować tytuł stałej rubryki (Pride 2015, 98). Obok wskazań, w co się ubrać, jakich nowych kosmetyków użyć, mamy również poradnictwo: „,co to jest ten kamp (o którym pewnie gdzieś słyszeliście, bo kojarzy się go z gejami, którymi jesteście)”. Nie chcę przekpić tej sprawy; nie sądzę, by redaktorzy Pride zasadniczo mylili się co do przeciętnej świadomości gejów. W istocie narracyjna strategia przewodnika waha się między „efektem Pana Jourdain” a próbami nieprzeintelektualizowanego zsyntetyzowania informacji na temat kampu. Innymi słowy, redakcja konstruuje taki komunikat: kamp jest w wielu miejscach dookoła was i stanowi część świata wielu z was, może w wielu wypadkach jest tym, co was odróżnia (wasz gust) od „większości” („większości rodaków, którzy powinni wyluzować”? Większości „heteryckiej”?), tym, do czego was ciagnie „intuicyjnie” czy „podświadomie”, a my teraz spróbujemy wam to uporządkować. Spójrzmy zatem, jak to jest realizowane.

\section{„Gejowskie diwy”}

W temat przewodni wprowadza przegląd pt. „Plastic Fantastic” (12-13), ilustrowany przykładami z zakresu nie zawsze cienkiej granicy kiczu i kampu. Wzmiankowane sa tu wokalistki z lat osiemdziesiątych: Cher (której poświęcony został także osobny artykuł na stronie 118), Madonna i Cindy Lauper, a także queerowi artyści męscy: David Bowie, Elton John, Boy George i zespół KajaGooGoo. Ta sekcja zahacza o kamp z dwóch powodów - po pierwsze, „odzyskuje” epokę oddaloną od chwili obecnej już o trzy dekady,

\footnotetext{
7 Np. Jacek Górecki rozpoczyna rozmowę z wokalistką Natalią Nykiel od stwierdzenia: „Tematem tego numeru PRIDE jest kicz i kamp" (Pride 2015c, 114).
} 
wydobywając z niej nie tylko wciąż oczywistą gej-diwę Madonnę, ale i mniej oczywistą dla młodszych czytelników, bo mniej ostatnio czynną Cher oraz dość już zapomnianą Cindy Lauper.

„Gejowskie diwy”8 i „odzyskiwanie” przeszłości, w tym nieoczywiste wybory tego, co jest „odzyskiwane”, opisywano w badaniach nad kampem (Ross 2012, 330, 343-346; Perkovich 2012, 158-159; Kleinhans 2012, 405-428). Oczywiście kamp - i w tym jest jego siła, ale i wiążące się z nim problemy - stale się zmienia i redefiniuje. W latach osiemdziesiątych teledyski Cindy Lauper można było uważać za kompletny kicz, nie kamp; kiedy Grzegorz Musiał opisywał lata siedemdziesiąte, jego kampowymi, odzyskiwanymi diwami były Hanka Ordonówna i Vera Bobrowska, a nie wokalistki Abby. Jednak dwadzieścia lat później w Priscilli, królowej pustyni (1993) Agnetha i Frida urosły do rangi kampowych diw9. Kamp w bardzo szczególny sposób pogrywa „patyną” czasu; szczególny, bo nie tylko melancholijny - co jest strategia dominująca, powiedzmy, w kulturze modernizmu - ale i nie tylko w sposób ironiczny, co znów byłoby dominująca strategią kultury postmodernizmu (rzecz, której nie zrozumiał Fredric Jameson Jameson 2011, 16-18, 33-34]), a będący wypadkową obydwu. To zaś odróżnia kamp od kiczu. Dlaczego jednak zabrakło wśród tych diw miejsca dla Beaty Kozidrak z lat osiemdziesiątych, Małgorzaty Ostrowskiej ${ }^{10}$, Zdzisławy Sośnickiej ${ }^{11}$, które wówczas także udatnie bawiły się plastikiem i z dzisiejszej perspektywy z pewnością są gejowskimi diwami? Otóż trzeba sprecyzować,

8 W pierwszym numerze magazynu także ukazał się o nich artykuł (Chilewicz 2014). W trzecim przeanalizowano musicale jako element kultury gejowskiej, co w badaniach nad kampem i kultura gejowska opisywano już w latach siedemdziesiątych (Kupka 2015a).

${ }^{9} \mathrm{~W}$ takiej funkcji Abba, ale także Alicja Majewska i Maryla Rodowicz, a nawet Shazza występują w powieści Pozytymni Maćka Millera, w scenie szpitalnego gay-party na oddziale zakażonych HIV (Miller 2005, 146, 154, 156159).

10 W 2015 roku Małgorzata Ostrowska włączyła się w akcję KPH i Repliki ,Jestem sojusznikiem osób LGBT" (podobnie jak Maryla Rodowicz czy Krystyna Mazurówna, a z nie-diw np. Zbigniew Wodecki). W 2016 roku udzieliła Replice wywiadu o znaczącym tytule „Wzajemnie się wyczuwamy”. Piosenkarka mówi tam, że wcześniej grywała już w klubach gejowskich, że publiczność gejowska podchodzi bardziej emocjonalnie do kultowej Meluzyny, która zagościła także w rankingu polskich przebojów tęczowych Repliki: „Myślę, że to kwestia tekstu. Nie ja go napisałam i znając autora [Krzysztof Gradowski, reżyser filmów o Panu Kleksie przyp. PS], nie został on napisany dla takiego oddźwięku. Ale myślę, że to ta inność, sytuacja nieco bajkowa i dotycząca innego rodzaju miłości - nie zawsze spełnionej, opowiedzianej w taki dziecięcy sposób. To historia miłości dwóch nietypowych i niepasujących do siebie istot, także miłości nieuznawanej przez poprawny świat". (Ostrowska i Górecki 2016, 10-11). Znamienne jest to, że Ostrowska przez lata nie grała na koncertach Melugyny, ta zaś gościła nieprzerwanie na imprezach gejowskich. Dopiero po 2010 roku coś się zmieniło, pokolenie trzydziestolatków zaczęło wyrażać nostalgię za latami osiemdziesiątymi, w tym za synth-popem, i Melugyna wróciła nie tylko z adresem kampowym. Przy okazji warto zauważyć, że moje pokolenie wychowało się na filmach o Panu Kleksie - a w nich wystąpiły i zaśpiewały piosenki wzmiankowane tu jako gejowskie diwy: Ostrowska, Rodowicz, Sośnicka, Kozidrak, ale też Edyta Geppert oraz Marlena Drozdowska.

11 Sośnicka jest wzmiankowana w innym miejscu - na stronie 103 w przeglądzie nowości wydawniczych jej dziewięciopłytowa antologia jest nazwana ,zdecydowanie najważniejszym wydawnictwem na polskim rynku muzycznym w 2014 r.’. Trzeba przyznać, że tak mocny sąd o tym wydawnictwie nie pojawił się bodajże nigdzie poza środowiskiem gejowskim i „kamperskim”. 
że zjawisko „gejowskich diw” splata się z kampem, choć nie zawsze są one tym samym. Innymi słowy, samo gay following jakiejkolwiek „diwy” czy zjawiska w ogóle (również stylu lub obiektu, a nawet słowa) może przybierać i najczęściej przybiera charakter kampowy, ale nie dotyczy wyłącznie kampowych obiektów czy osób. Krótko mówiąc, nie wszystkie gejowskie diwy są nimi dlatego, że są kampowe. Barbra Streisand i Donna Summer, Agnetha i Frida, Whitney Houston nie sa kampowe, ale sa gejowskimi diwami, a ich kult jest kampowy. Istnieja jednak takie diwy jak Shirley Bassey, Eartha Kitt, Grace Jones, Bette Midler, Dana International, La Lupe (Kubanka „odzyskana” przez Almodóvara), które są kampowe i są obdarzane kampowym kultem. W polskiej kulturze do uwielbianych przez gejów diw należą Violetta Villas, Zdzisława Sośnicka, Maryla Rodowicz, Beata Kozidrak, Izabela Trojanowska, Gayga - i te są kampowe. Jednak panteon obejmuje także Annę Jantar, Alicję Majewską, Krystynę Prońko, Korę, Małgorzatę Ostrowską, Edytę Górniak, Helenę Vondračkovą (jako osobnej kategorii przykład środkowoeuropejskiego, socjalistycznego kampu polskich i czechosłowackich gejów), Justynę Steczkowską być może Halinę Frąckowiak (dla mnie tak); wszelkie cechy ku temu ma także Urszula, ale wymienione wokalistki kampowe nie są (być może Steczkowska balansuje na pograniczu) ${ }^{12}$. Dość cienka

12 Stosunek gejów do diw to jedno, a stosunek diw do środowiska LGBTQ czy „praw osób homoseksualnych” to zupełnie inna kwestia. Nie jestem pewny, czy ktokolwiek pytał o tę kwestię Violettę Villas i czy miała ona świadomość uwielbienia, jakim osobliwie darzą ja geje - można się tylko domyślać, że z powodu (kampowej rzecz jasna) dewocji komentarz taki nie byłby „po jej myśli”. Część piosenkarek zapewne rozpoznaje tę publiczność i odnosi się do niej z sympatia, ale wyrażaną dyskretnie bądź wcale - to bodajże przypadki Zdzisławy Sośnickiej czy Edyty Górniak. Czechy zelektryzowała niedawno wypowiedź ich naczelnej gej-diwy, asymilowanej także przez polskich „kamperów”, Heleny Vondračkovej, bardzo wstrzemięźliwej w entuzjazmie wyrażanym wobec praw LGBTQ. Z jednej strony, w wywiadzie udzielonym w Polsce Pawłowi Piotrowiczowi piosenkarka rozpoznała i pochwaliła tę publiczność: „Dwukrotnie, w 2009 i 2010 roku została pani uznana za ikonę przez homoseksualistów - zwyciężyła pani w plebiscycie Gay Stars w kategorii Gay Personality. Trzykrotnie, w tym roku zaszczycono mnie ponownie. Ma pani pomysł, z jakiego powodu? Nie wiem [śmiech]. Ale nie mam nic przeciwko. Homoseksualiści zawsze mnie lubili, może podobał im się mój sceniczny wizerunek, choreografia? Widocznie w jakiś sposób ich inspiruję. Ale to bardzo dobra publiczność, bardzo muzykalna" (Vondráčkova i Piotrowicz" 2013). Z drugiej strony, w 2014 roku wypowiedziała się przeciwko rodzinom homoseksualnym, mówiąc: je to anomálie [to anomalia] („Jak nas gay ikona Helena Vondrackova..." 2014). Podobne wahania dostrzec można w wypowiedziach Justyny Steczkowskiej, której gejowscy fani zrealizowali w 2008 roku teledysk do piosenki Wracam do domu o miłości dwóch mężczyzn. W 2012 roku inni gejowscy fani - producenci muzyczni - stworzyli gejowski teledysk do piosenki Ukołysze nas sitowie, zaakceptowany przez Steczkowska. Jednak jej sympatie bywały różne, a największy wpływ na nie miało przypuszczalnie to, czy w tym czasie popierała prawicowe partie, czy nie. Wprost zagadnięta na swojej stronie internetowej przez fana, odpisała: „Kochany Marcinku! Uwielbiam ich. Mam wielu znajomych o odmiennej orientacji, a wśród nich dwóch oddanych przyjaciół, na których zawsze mogę liczyć. Wiem, że czasami jest Wam trudno żyć w społeczeństwie, ale ja jako osoba publiczna mam podobne problemy braku akceptacji, czasami wytykania palcami. Powiem $\mathrm{Ci}$, że w takich momentach jest mi wstyd za tych ludzi, że zapominaja o tolerancji $\mathrm{i}-\mathrm{w}$ tak bardzo chrześcijańskim społeczeństwie - o słowach, które są podstawą naszej wiary: »Kochaj bliźniego swego jak siebie samego«. Pozdrawiam (Steczkowska)”. Krystyna Prońko nie wygłaszała publicznych komentarzy na ten temat, ale konsekwentnie koncertuje w gejowskich klubach od połowy lat dziewięćdziesiątych, kiedy to takie występy wcale nie były popularne wśród artystów (dodam, że problemu z koncertowaniem w gejowskich klubach nie miał także Robert Gawliński w solowym etapie swojej kariery). W numerze Repliki, który ukazał się w tym samym czasie, co omawiany numer Pride, Maryla Rodowicz wzięła udział w akcji Kampanii Przeciw Homofobii „Ramię w ramię po równość” jako oficjalna sojuszniczka osób 
granica biegnie tu między „wykonywaniem zawodu na poważnie”, co wiąże się z mainstreamowym appealem, a „kobieca przesada” (female excess), o której pisała Pamela Robertson, analizując m.in. to, co pociaga gejów w określonych ikonach (Robertson 2012, 43-44). Temat kampowego panteonu i diw powraca w stałym cyklu rankingu zjawisk. W omawianym numerze Pride jest to ranking „69 świrów, którzy nakręcają świat” (Pride 2015, 48-69). To nie pierwszy ranking noszący znamiona kampowego dyktatu (choć jak w przypadku wielu tekstów z tego numeru nie pojawia się tu hasło „kamp”). Po pierwsze, jest on dość arbitralny, co oznacza, że tylko połowicznie liczy się z tym, co bieżąca postać mainstreamu uznałaby za godne uwzględnienia w jakimkolwiek rankingu. Uzasadnienia w niektórych (ale tylko niektórych) przypadkach przypominaja słynny słownik Philipa Core’a Camp. The Lie that Tells the Truth, wyraźnie jednak uproszczony i pozbawiony pazura ${ }^{13}$. Oczywiście ranking ów również „odzyskuje” (a przeto i poucza - tych najmłodszych). Uwzględnia on więc zarówno dość oczywiste współczesne diwy (Rihanna, Peaches, Miley Cyrus, Nicki Minaj, Lady Gaga), jak i diwy mniej dziś oczywiste (Cindy Lauper, Grace Jones, Kate Bush); współczesne postaci ogłaszające swoje wsparcie wobec środowisk LGBTQ w sposób mało „asymilacyjny”, za to z przytupem (czyli tak, jak działa kamp, co oczywiście nie oznacza, że postaci te są kampowe: Dorota Wellman, Perez Hilton, Maria Czubaszek, Kuba Wojewódzki); historyczne ikony czynne także współcześnie (Tilda Swinton, Krystyna

LGBT (Replika 2015, 3). W tym samym numerze Sergiusz Wróblewski, niegdyś redaktor Inaczej, wspominał: „Z gwiazd - choćby Kora, Małgosia Ostrowska czy Maryla Rodowicz, która okazała się wspaniałym człowiekiem także prywatnie. Gdy w 2005 r. policja zatrzymała mnie podczas poznańskiego Marszu Równości, a telewizja to pokazała, Maryla zatelefonowała do mnie z pytaniem, czy nie potrzebuję np. pieniędzy na adwokata" (Wróblewski i Górecki 2015, 30). Może najgłośniej o prawach osób LGBTQ mówiła właśnie wzmiankowana Kora, która zrealizowała teledysk nt. przemocy homofobicznej do piosenki Maanamu Wolno płyną łodzie już w 2001 roku, a więc zanim temat homoseksualności wszedł do głównego nurtu debaty publicznej. Jeśli chodzi o przykłady światowe, ikoniczne są przypadki Bette Middler, która po prostu rozpoczęła karierę w klubach gejowskich, a także Donny Summer oraz Whitney Houston, którym przydarzyły się dość niefortunne wypowiedzi. Summer właśnie się nawróciła i u progu epidemii AIDS wyraziła się o tej chorobie jako o „karze boskiej”. Później twierdziła, że jej słowa przekręcono i wielokrotnie przepraszała publicznie, deklarując sympatię dla gejowskich fanów. Houston śpiewała na paradach równości. Jej przypadek jest o tyle skomplikowany, że była narkomanką i do tej pory nie jest jasne, czy nie była w długotrwałej, ukrywanej lesbijskiej relacji.

13 Najbardziej widoczne jest to w przypadku haseł o tych samych osobach. Hasło o Liberace: „Był jedna z największych atrakcji królestwa amerykańskiego kiczu, czyli Las Vegas. Polak. Ekscentryk. Ikona. Władziu. Zakochany w sobie, narcystyczny, ale także niezwykle utalentowany. Nie grał koncertów, on robił prawdziwe show pełne rozbuchanych pomysłów scenograficznych i kostiumowych. Ludzie byli w nim zakochani, kiedy mówił do nich ze sceny: »jesteście cudowną publicznościa. Najchętniej nie wziąłbym od was pieniędzy za bilety. Niestety to zrobię«" (Pride 2015c, 60). Co jest najbardziej kampowego w tym haśle? Słowa Liberace... Choć echo kampu jest też dostrzegalne w kapryśnym ciagu: „Polak. Ekscentryk. Ikona. Władziu”. A oto fragment ze słownika Core'a: ,the man with the piano-shaped rings and the sequinned jackets, personifies the kind of camp that is kitsch. His talent - that of a nineteenth-century virtuoso applied, inappropriately, to modern trifles - is like using a gold-plated trash can for oridinary garbage, but his style is the highest level of low camp. [...] His world-wide following consists of devoted ladies d'un certain age who ape his ostentation; where possible they actually look like Liberace would if he allowed his ostentation to tip over into drag" (Core 1984, 122). Jak widać, autorzy notek nieco inaczej sytuują także adresatów (adresatki) tych performansów (wszyscy vs panie w pewnym wieku). 
Mazurówna, Björk); egzotyczne ikony innych kultur (kampowa diwa Almodóvara, Rossy de Palma); ikonicznych gejów (Oscar Wilde, Liberace, Freddie Mercury, Boy George).

\section{Kamp a pop raz jeszcze}

Wróćmy do artykułu o estetyce plastikowej, który znajduje się na pierwszych stronach Pride. Do szczególnie istotnych, omówionych w nim obiektów i zjawisk należą różowe flamingi oraz historia ich przechwycenia - czy adopcji - przez gejów jako symbolu środowiska i osoby homoseksualnej. Rozpoznania i prezentacje kolorowej i/lub plastikowej estetyki wracaja jeszcze w kilku miejscach, w niektórych przypadkach w odniesieniu do zjawisk kampowych, w innych niekoniecznie. Na stronie 47 zaprezentowano powrót do jaskrawych kolorów jako powrót do lat dziewięćdziesiątych (zegarki, okulary przeciwsłoneczne i buty - wszystkie niekampowe). Następnie znajdziemy tu tekst o zjawisku kampu (o którym poniżej), po czym, co ciekawe, trafiamy na prezentację mody pod hasłem Art Pop (projektanci ChomiSawa i Dream Nation; 82-91), należącej w istocie, zgodnie z nazwă, do estetyki pop-artu, a nie kampu. De facto problem mieszania się popu i pop-artu z kampem - do którego Susan Sontag za sprawą swojego fundamentalnego tekstu niestety przyłożyła rękę - był dostrzegany już w latach sześćdziesiątych (Ross 2012, 342-346). Do takiego splątania prowadzą również działania redakcji Pride - nie sądzę zreszta, by były to działania nieświadome, bowiem tuż po zdjęciach z kolorowa modą zaprezentowano tu sylwetki i szereg prac kultowego duetu Pierre et Gilles (92-97), tworzącego bardzo świadome, kampowe dzieła. Następnie trafiamy na krótki esej o „winnych przyjemnościach”, tekst o drag queens (tak mocno kojarzonych z kampem, że w zasadzie już niekampowych; 120-125), przegląd stylizacji z teledysków z późnych lat dziewięćdziesiątych (142-145), niekampowych, a kiczowatych w złym tego słowa znaczeniu. Jako finalny akord rozbrzmiewa natomiast prezentacja projektów Karima Rashida (184-189), ocierających się o kamp.

Twierdzę, że redaktorzy umyślnie pomieszali różne zjawiska: kamp z popem i popartem, a także z kiczem i kolorową estetyką. Nie mogę wchodzić w szczegóły i dokonywać subtelnych rozróżnień, dlatego zilustruję rzecz przykładem. Lata dziewięćdziesiąte w istocie były kolorowe, ale kamp to złożona nadwyżka seksualnej prowokacji i przede wszystkim mniejszościowego smaku, które są w istocie zaprzeczeniem celów i ideałów popu. To, że niekiedy mniejszościowy smak „,chwyta” w mainstreamie, co zresztą trudno uprzednio skalkulować, to już inna rzecz. Proponuje przypomnieć sobie kolorowe i animowane, komiksowe teledyski zespołu E-rotic, np. Help Me Dr. Dick (1996), zabawne, śmieszne, seksualne i prowokacyjne, ale nie w sposób queerowy, a więc w efekcie - niekampowe. Porównajmy je z dwoma teledyskami niemieckiego wykonawcy Sin With Sebastian, Shut up 
and sleep with me oraz Golden boy (obydwa z 1995 roku), prowokujące przegięciem oraz epatujące obrazem „kolorowej i lubieżnej cioty” (która uważa, że nie ma facetów hetero, są tylko faceci źle podrywani). Uroczy przykład kampu lat dziewięćdziesiątych. Dlaczego chwycił? Sądzę, że chwyciły melodia i aranż, a resztę przełknięto mimowolnie. O takich klasykach z lat dziewięćdziesiątych, którzy na wieki zapisali się złotymi zgłoskami w wielkiej księdze kampu - jak Army of Lovers - w ogóle już nie wspominam.

Odpowiedź na pytanie, dlaczego świadomie pomieszano kamp z odmiennymi (acz pozornie podobnymi) postaciami estetyki, bynajmniej nie wymaga konstruowania teorii spiskowej. Otóż Pride apeluje raczej do gustu popowego, do jakiejś wersji „gejowskiego mainstreamu” czy „gejowskiego aspirującego mieszczaństwa", które jest nieco inne niż „niegejowski (czyli faktyczny) mainstream” - wciskanie się takich nieoczywistych śladów wskazywałem wyżej choćby na przykładzie rankingu - a nie do estetyk awangardy, ryzykanckich, wywrotowych. Przyswaja je raczej i asymiluje, włącza w swój zakres na własną modłę.

Pora na parę ogólniejszych wniosków. Richard Dyer pisał w 1976 roku, a więc w czasach rozkwitu gay liberation w Stanach Zjednoczonych: „kamp jest tak urzekający, że ostatnimi czasy adoptuje go wielu normalsów. [...] Kiedy jednak kamp jest przejmowany przez heteryków, dzieje się z nim coś dziwnego - traci ostrość, identyfikację z doświadczeniem gejowskim, dystans do heteroseksualnego spojrzenia na świat" (Dyer 2012, 88) ${ }^{14}$. Podobnie ujmował rzecz Mike Perkovich: „Kamp parodystycznie i ironicznie utożsamia się z odmieńcem. Kiedy jest zawłaszczany przez normalsa próbującego umacniać struktury dominującego natural(izowa)nego porządku, nieodmiennie zawodzi i kompromituje takie usiłowania" (Perkovich 2012, 152-153). Czy faktycznie jesteśmy w Polsce w takim momencie, w którym geje nie wiedza, czym jest kamp? Czy trzeba im tłumaczyć kamp oraz przechwytywać go? Tak jak kiedyś kultura „większościowa” przechwytywała go z gejowskiej, tak teraz kultura gejowska przechwytywać ma go z kultury gejowskiej zaprzeszłej? Ponieważ kultura kampu - a w każdym razie pewnej jego historycznej postaci miała wyraźny związek z opresją, stawiano tezę (nawiązuje do niej także Dyer), że wraz z postępująca widocznością i jawnościa gejów kamp jako „tajny język” stanie się po prostu nieaktualny, niepotrzebny. Tak się jednak (oczywiście!) nie stało. Kamp mutuje, zmienia się historycznie, antycypuje i osiąnąwszy pewną rozpoznawalna pozycję, w zasadzie natychmiast ją opuszcza, aby dalej być w kontrze do instytucji „normalności”. Dlatego do historii kampu przynależą filiacje z popem, choć moim zdaniem, jeśli w ogóle mamy zachować pojęcie kampu w dyskursie akademickim i potocznym, to należy je wyraźnie od popu odróżniać,

\footnotetext{
14 Oraz: „Kamp normalsów sprawia więc, że mocne wizerunki płci zachowuja swoje wpływy nawet wtedy, gdy równocześnie manifestuje się ich odrzucanie. [...] Nie cały kamp gejowski jest faktycznie postępowy, niemniej jednak ma ku temu potencjał" (Dyer 2012, 89).
} 
a na pytanie „w jaki sposób?” odpowiadałbym: według mniejszościowego adresu i krytycznego ostrza skierowanego w aktualne postaci „normalności”. Tę właśnie dystynkcję w Pride zatarto. Wiele racji miał Dennis Altman, który w kwestii przemian kampu stawiał inną tezę: „Obecny spadek zainteresowania większością form kampu i kultury drag jest zapewne nieunikniony, wziąwszy pod uwage potrzebę potwierdzenia nowego pojmowania tożsamości” (1982, 153-155). Altman sugeruje, że być może to nie „widoczność” jako taka spowodowała odwrót od kampu, ale raczej rozwój „gejowskiej tożsamości” - poprzez ekonomię, czyli przez, krótko mówiąc, „gejowski kapitalizm”.

Pora zerknąć do kluczowego tekstu w numerze, w którym wyjaśniono czytelnikom, czym jest kamp. Odbiorca oczytany w teoriach kampu widzi, że Joanna Filipiak, autorka artykułu „Z tęczową soczewką w oku”, zna literaturę przedmiotu i wie więcej, niż w tekście zawarła, umiejętnie przetwarzając trudniejszą materię na przystępny język. Tytuł zasadnie podkreśla, że jest to estetyka powiązana z gejostwem. Filipiak wydobyła jednak z Sontag pewną wątpliwą tezę (aczkolwiek zniuansowała ją na swój użytek), która dość dobrze współgra z ogólna polityka pisma Pride, to znaczy z polską wersja ,gejowskiego kapitalizmu”. Teza ta została zreszta powtórzona w tzw. leadzie na ostatniej stronie - głosi ona, że kamp to smak snobistyczny i prerogatywa elity, jest on więc obecny tylko w bogatych społeczeństwach, w których możliwa jest patologiczna konsumpcja. Pisząc o środkowoeuropejskiej odmianie kampu w warunkach realnego socjalizmu, zakwestionowałem to założenie i wskazałem na „ślepa plamkę” w studiach nad kampem, które przeoczaja jego uwikłanie w kapitalistyczną logikę fetyszyzmu towarowego (Sobolczyk 2015). W skrócie: istnieje kamp ubóstwa, Genetowskich złodziei i prostytutek, historycznych drag queens z lat pięćdziesiątych i sześćdziesiątych, które na ogół były biedne (Medhurst 2012, 138); i bynajmniej kamp nie powstaje poprzez aspirowanie do klasy wyższej „na serio”. Kamp ironizuje na temat wszystkich tych kwestii. Autorka ma tego świadomość, gdy pisze:

Trudno spotkać Polaka, który zupełnie szczerze, nie zająknąwszy się, powie o Polsce, iż płynie ona mlekiem i miodem, a jednak estetyka przesącza się do nas wszystkimi kanałami. [...] Trudno więc mówić o Polsce jako empatyzującej z psychopatologia dobrobytu. To raczej mimikra, rafa koralowa, ładna, ale podatna na każdą fluktuację, z delikatnym, zależnym od czynników zewnętrznych ekosystemem (Filipiak 2015, 81)15.

15 Por. też trafną uwagę problematyzującą klasowość i pokazującą przechwycenie kampu przez główny nurt: „Nawet dresiarze, podejrzewam, używają filtrów do przerabiania zdjęć, a już na pewno dresiarze z awansu, biegający razem z posłem Wiplerem na Mazowiecka, by dobrze się zabawić, a następnie ślad tej zabawy pozostawić w sieci. Widać to było na plakatach wyborczych Andrzeja Dudy, który został przekolorowany 
Polska w dwudziestym pierwszym wieku nie potrzebuje - już? - „kapitalistycznego kampu”.

\section{Kampowa pogoda dla bogaczy?}

Problem polega na tym, że magazyn Pride od początku opierał swoją konstrukcję odbiorcy modelowego właśnie na jego domniemanym aspirowaniu do klasy wyższej niż wyjściowa. Otóż jest to pismo adresowane do klasy, która w Polsce nie istnieje. Moim zdaniem działa tu mechanizm znany z reklam pewnych czekoladek, konsumowanych przez damy w futrach, w limuzynie, konwersujących z szoferem - a że czekoladki te są odpowiednio droższe, acz powszechnie dostępne, to zachodzi podejrzenie, że ich producenci mają sprzedawać biednym marzenie: może nie będziesz bogaty, ale zjadając (a przede wszystkim kupując) taką czekoladkę, na chwilę znajdziesz się w tym samym miejscu co „elita”. Zostawmy już na boku kwestię, że naprawdę zamożni ludzie tych czekoladek nie jedzą i że nie są one specjalnie smaczne, raczej głównie drogie.

Nie będę gołosłowny i podam kilka przykładów, choć analizie zjawiska można by poświęcić cały artykuł. Pozostawiam bez szerszego komentarza np. reklamy apartamentowców, które moga kupić tylko ludzie z listy najbogatszych Polaków, a o ile mi wiadomo, nikt z nich nie jest jawnie homoseksualny. Rzecz jasna kreowany czytelnik Pride jest wyoutowany. Co więc Pride poleca zakochanym parom na „zimowe wakacje we dwoje” (czy raczej we dwóch)? Jedyny siedmiogwiazdkowy hotel na świecie znajdujący się w Dubaju, ceny już od 1500 do 25000 dolarów (Pride 2015a, 12)16. Patryk Chilewicz przekonuje, że najskuteczniejszym narzędziem nacisku politycznego jest ekonomia, czyli - uwaga „gejowski kapitalizm” (Pride 2015a, 48-51), działający w myśl zasady: ,jak będziemy bogaci, to będą musieli nas szanować". Artykuł o urządzaniu wspólnego mieszkania zilustrowany został materiałami prasowymi dotyczącymi „The Prime”, czyli, dla niewtajemniczonych, właśnie powstającego, blisko stumetrowego biurowca na warszawskiej Woli (Pride 2015b, 184-189). Magazyn przeplatany jest treściami w mniejszym stopniu nacechowanymi prokonsumpcyjnie, niemniej trudno uznać, że Pride reprezentuje świat gejów-studentów a jest to być może najwidoczniejsza grupa gejów, co można wywnioskować, używając aplikacji typu Grindr lub bywając w klubach („widoczność” i „znikanie” to jednak tematy

w Photoshopie na modłę Warholowską. Całe to globalne mutowanie kultury posługuje się logiką kampu" (Filipiak 2015, 80).

16 Poza tym zachęcanie gejów do odwiedzania kraju, w którym za homoseksualność grozi kara śmierci (Dubaj co prawda ma bardziej liberalne prawo niż reszta kraju - kara wynosi 10 lat więzienia), nosi znamiona czarnego humoru. 
godne osobnych analiz) - gejów małomiasteczkowych czy w ogóle kogoś innego niż środowisko bogatych gejów warszawskich. Dlatego przesłanie magazynu brzmi nie tyle „konsumujcie”, co raczej „aspirujcie”. Chcę podkreślić, że taki światopogląd nie stanowi żyznej gleby dla kampu.

\section{Winne zabawy i „beka”}

Drugi tekst problemowy (w odróżnieniu od artykułów ilustracyjnych) opublikowany w czwartym numerze Pride to „Guilty Pleasures” Tomasza Kupki, znacznie krótszy od artykułu o kampie (110-111). Redakcji należy się pochwała za to, że wprowadza kategorię słabiej obecną w świadomości nieeksperckiej (a i w eksperckiej nie dość obecną, w Polsce bodaj wcale). Proponuje prosty polski odpowiednik „winne zabawy”, ponieważ wyraźnie nawiązuje on do zbitki „niewinna zabawa” (ta zaś ma konotacje erotyczne: „- co tam Staś z Jasiem robia za fotelem z tymi łopatkami? - to takie niewinne zabawy...”), przy okazji przywodząc na myśl też smak, i to smak teoretycznie zastrzeżony dla grup 18+. Błąkały się tu i ówdzie określenia typu „grzeszne przyjemności”, ale guilty to nie „grzeszny”, zreszta nie ma co podsycać polskiego zafiksowania na kategorii „grzechu”.

Moim zdaniem kilka rzeczy powinno zostać doprecyzowanych w związku z artykułem Kupki. Niezasadnie autor próbuje przypisać adres tej kategorii „wszystkim”, po chwili sobie zaprzeczając:

\footnotetext{
Zasadniczo pojęcie (używane od lat dziewięćdziesiątych) odnosi się do wytworów kultury popularnej i jej konsumentów, czyli nas wszystkich. Niektórzy zapewne odrzuca całkowicie sam koncept, bo i dlaczego coś, co sprawia nam przyjemność, miałoby jednocześnie wywoływać w nas poczucie winy (Kupka 2015, 111)?
}

Druga istotna kwestia - jak za chwilę wyjaśnię, związana z problemem adresu - to pytanie o relację kategorii guilty pleasures do kampu. Nie jest jasne, czy Pride utożsamia te dwa pojęcia bądź traktuje jedno jako część drugiego, ponieważ, jak wspomniałem, kategoria kampu jest tu na tyle wszechobecna, że prawie jej nie ma. Pamela Robertson, teoretyczka, która pchnęła rozważania nad kampem na nowe tory, stawiając pytanie o kobieca publiczność kampu i pozycję kobiet jako „przedmiotów” czy „obiektów” (czasami „wykonawczyń”) kampu, w tytule swojej książki użyła właśnie kategorii guilty pleasures. Zajęła się teoretycznymi i praktycznymi rozpoznaniami kampu, zatem najprawdopodobniej uznała, że uczestnictwo w kampie - być może tylko dla kobiet - jest taką właśnie „winną zabawą” (Robertson 1996). 
Otóż moim zdaniem „winne zabawy” choćby dlatego są kategorią odrębną, że kamp, wbrew inspiracjom płynącym od Sontag, występuje w różnych klasach, a przynajmniej występował, ponieważ współcześnie pojęcie „klasy” znaczy coś innego niż w latach pięćdziesiątych i sześćdziesiątych, także z tego powodu, że zmieniła się postać kapitalizmu. Krótko mówiąc, „winne zabawy” są kategorią wyraźnie powiązaną z klasą (czy grupa społeczna, ponieważ ludzie aspirujący czy należący do „inteligencji” funkcjonuja w bardzo różnych warunkach ekonomicznych) „inteligencji”, albo - jak postuluję - z „klasą kreatywną”. Zamiast rozpisywać rzecz na abstrakcyjnych kategoriach, podam dobry, jak myślę, a do tego polski przykład: disco polo.

Powinniśmy na boku zostawić kwestię, czy disco polo miało inteligenckie, a przeto pastiszowe początki. Jeżeli początków disco polo szukać w próbie zaadaptowania w Polsce italo disco, to znaczy w Daj mi te noc zespołu Bolter (1985), to musimy pamiętać, że utwór ten napisał absolwent kompozycji na Akademii Muzycznej (Sławomir Sokołowski) i, abstrahując od doskonałej pastiszowej aranżacji, jest to znakomicie napisana melodia (co można też powiedzieć o piosenkach Papa Dance). Nie dziwota więc, że piosenka ta wraca jako „winna zabawa” w coverach artystów uchodzących aktualnie za „ambitnych” (np. Marika, IncarNations, Ballady i Romanse). Jeżeli przyjąć, że piosenką założycielską dla nurtu disco polo jest - wówczas określane mianem „piosenki chodnikowej” - słynne Mydełko Fa Marleny Drozdowskiej, to również jego początki jawić się będą jako pastiszowe i inteligenckie: Drozdowska ukończyła klasę wokalną w szkole muzycznej, autorami tekstu i muzyki byli Andrzej i Mikołaj Korzyńscy (ten pierwszy to absolwent kompozycji i dyrygentury na Akademii Muzycznej oraz, jak powszechnie wiadomo, kompozytor wielu przebojów i soundtracków, m.in. kultowych piosenek do filmów o Panu Kleksie), a w nagraniu głosu użyczył także znakomity aktor Marek Kondrat, co zresztą później mu wypominano, ignorując fakt, że piosenka była pastiszem. Nawet jeżeli uznamy, że początki disco polo wiążą się z działalnością zespołu Top One, to również trzeba stwierdzić, że jego produkcje zawsze stały na wyższym poziomie niż główny nurt disco polo. W tej chwili jednak interesuje mnie właśnie ów główny nurt, który pojawił się około 1991-1992 roku. Dla ówczesnych fanów muzyka ta z pewnościa nie była „winna zabawa”, ponieważ oddawali się oni tej przyjemności bezwstydnie. To „inteligencja” czy aspirujący do niej - ludzie posiadający bądź pracujący na pewien kapitał kulturowy - krytykowali tę muzykę jako „obciach” i „żenadę”. Jeżeli jej słuchali, to pokątnie i z pewnym poczuciem zażenowania. Okoliczności łagodzące stanowiły np. alkohol lub sytuacja społeczna taka jak wesele (nie mam wpływu na to, co grają, a jestem tak pijany/pijana, że nie ma znaczenia, czy mi się to „podoba”).

Disco polo nie było również kampowe. Natomiast z pewnej perspektywy czasowejperspektywy naznaczonej większą widocznością homoseksualności w przestrzeni publicznej, większą rozpoznawalnościa jej stylów - można postawić pytania, których wówczas chyba 
nie można było zadać. Dzisiejszemu widzowi patrzącemu „z ukosa”, queerowemu widzowi, oglądanie występu Zenona Martyniuka i zespołu Akcent, wykonujących słynny hit Życie to sa chwile z 1994 roku (,życie to są chwile, chwile / tak ulotne jak motyle”), choćby nagranie z Sali Kongresowej $(1995)^{17}$, przywodzi na myśl pytanie: jak to możliwe, że nikt wówczas nie uznał tego za gejowskie? Szczególna kategoria męskości, związana nie tylko ze stylizacją ciała, ale i z performansem tanecznym oraz gestykulacja, w połączeniu ze zmanierowanym głosem $^{18}$ (co jest raczej skutkiem braku techniki wokalnej) dziś niemal automatycznie przywołuje kategorię: „gejowskie”. Nie chodzi o to, czy słusznie (zdaje się, że nie) interesuje nas pytanie o przestrzeń, w której zachowania stygmatyzowane w innych kontekstach stawały się niewidoczne i niegroźne. Zasadniczo ideologia tekstów piosenek disco polo jest konserwatywnie heteroseksualna, zawierają one też lubieżne wtręty ludowe („,hodź chodź chodź usiądź na kolanka / chodź chodź chodź pokażę ci bananka”19 - wprost odnosi się do ludowych piosenek; weźmy przykład takiej przyśpiewki tradycyjnej z lubelskiego: „W moim ogródecku rośnie rózycka / napój mi maniusiu mego kunicka / nie chcę, nie napoję / bo się kunia boję, bo się kunia boję / bom jesce młoda"). Wraz ze szczególną konstrukcją męskości ideologia ta tworzy jednak hybrydę, którą dziś możemy uznawać za kampową i w związku z tym czynić z niej sobie „winną zabawę”, ale pamiętajmy, że są to kategorie naddane wskutek czasowego dystansu (i zmian kulturowych oczywiście).

Od kilku lat w polskiej kulturze disco polo powraca: muzycy (np. Marcin Miller z zespołu Boys) sa zapraszani do „poważnych” czy mainstramowych talk-shows, piosenki disco polo sa wykonywane w muzycznych programach telewizyjnych (rzeczone Życie to sa chwile zostało znakomicie wykonane przez Kubę Molędę, artystę musicalowego, w programie Polsatu Twoja twarz bržmi znajomo, przynosząc artyście zwycięstwo odcinka), w centrach miast powstaja kluby disco polo (np. w Krakowie), gdzie ciagną tzw. hipsterzy, czyli młodzież o wysokim kapitale kulturowym i aspiracjach do awangardy smaku - „klasa kreatywna”. W tych przypadkach działa właśnie mechanizm „winnej zabawy” albo podobnej do niej, choć jednak nieco odmiennej (nie podejmę się ich rozróżnienia) „beki”. „Beka” to potocznie śmiech i rozbawienie, ale niekoniecznie wyśmiewanie się. Jeśli więc „poszliśmy do klubu disco polo dla beki”, to nie po to, by naśmiewać się z tych, którzy poszli tam „na serio”, a raczej po to, by śmiać się z samych siebie jako celebrujących „winną zabawe”". W takim rozumieniu „beka” ma więcej wspólnego z kampem, choć związany z nią ironiczny śmiech wprowadza wyraźny dystans podmiotu do wykonywanej czynności, który ma, jak myślę, charakter „ubezpieczający”: „ja się z tego śmieję, ale wszyscy wiedza, że tak naprawdę...”. Tymczasem

\footnotetext{
17 https://www.youtube.com/watch?v=kMtx3xbR_d8 (dostęp: 6.06.2015).

${ }^{18}$ Dotyczy to esmisji płaskiej i beczącej z tendencją do hiperpoprawnej artykulacji głosek „a”, „e”, albo do śpiewania bułki przez bibułkę..

19 Zespół Redox, piosenka Bananek z 1994 roku.
} 
w przypadku kampu, także tego niebędącego udziałem osób z klas nieinteligenckich, nie jest to zabezpieczenie tak oczywiste. Jeżeli „bekę” miałoby charakteryzować zdanie: „jestem ponad to, ale potrafię w tym uczestniczyć, tak jak prostsi ludzie”, to kampowa tricksteria działałaby zgodnie z rozpoznaniem: ,jestem lordem, dandysem i teraz urządzę sobie na ulicy jednoosobowy konkurs: kto zrobi większy balon z gumy do żucia”, czy też - posłużmy się dobrymi polskimi przykładami literackimi - ,jestem barokową damą z wysokiej arystokracji (i trzymam w mojej peruce pułapkę na pchły)" ${ }^{20}$. W drugim przypadku chodziłoby zatem o obniżanie i kompromitowanie własnych (i cudzych oczywiście) pretensji i aspiracji do „wyższości”. Podobny efekt można osiagnąć poprzez działanie odwrotne, zgodnie z zasada bottom-up: jestem żebrakiem w łachmanach, ale posiadam bajeczny pałac pod Buenos Aires (lub: jestem bogatym arystokrata posiadającym pałac pod Buenos Aires, ale do Retiro idę w szatach żebraka) ${ }^{21}$.

Na mechanizmie „beki” i związanej z nią „,winnej zabawy”, nie zaś na „kampowym odzyskiwaniu", oparty jest niedawny hit polskich ekranów, Disco polo w reżyserii Maćka Bochniaka (2015)22. Mimo to w postaci Rudego, umiejętnie zagranej przez Piotra Głowackiego, dadzą się dostrzec bardzo delikatne aluzje czy sugestie na temat jego nieheteronormatywności. To znaczy, że Bochniak, Mateusz Kościukiewicz, (współscenarzysta) a być może również Głowacki, zbierając materiały do filmu, spojrzeli na niektórych wykonawców disco polo „z ukosa”, okiem queerującym. Kiedy już wypatrzymy ten kontekst $\mathrm{w}$ filmie, jednym $\mathrm{z}$ tematów tego obrazu staje się jeszcze jedna przestrzeń „szafy”. Ale aluzje te są bardzo dobrze ukryte - oglądałem film z rodzicami i żadne z nich na ten subkod nie wpadło (a nie są oni jakoś szczególnie niedowidzący w kwestii homoseksualności). Dawid Ogrodnik z grzywką jako wokalista fikcyjnego zespołu Laser, postać bez wattpienia heteroseksualna, udatnie stylizuje się m.in. na wzmiankowanego Martyniuka i nawet wykonuje jego hit Pragnienie mitości. To jednak pozwala postawić pytanie o sam zwrot ku autopastiszowi w obrębie disco polo, który ociera się o jakąś postać kampu. Pragnienie mitości to piosenka z 2004 roku. W porównaniu z tekstami królującymi w latach dziewięćdziesiątych słowa tego hitu zawierają zaskakująco „barokowe” metafory, zdradzające dystans autora (Martyniuka) i - chyba - jego „bekę”:

${ }^{20}$ Luźna parafraza fantazji Michaśki i Pauli z Lubiewa Michała Witkowskiego.

21 Aluzja do postaci Gonzala z Trans-Atlantyku Witolda Gombrowicza.

22 W 2015 roku w ogóle przydarzył się polskiemu kinu „moment kampowy”. Chodzi o filmy muzyczne. Disco polo reprezentuje hipsterską „bekę”, Polskie gówno Grzegorza Jankowskiego ze scenariuszem Tymona Tymańskiego (2014, premiera kinowa 2015) - pogranicze kampu i punka oraz „winną zabawę”, zaś Córki dancingu (2015) Agnieszki Smoczyńskiej - feminist camp, wedle formuły Pameli Robertson. 
Chcę być twoją słodką mleczną czekoladka, / żebyś mogła chrupać mnie całymi dniami. / Chcę pomadką być do twojej buzi mała, / by całować usta twoje przez czas cały. / Chcę być gąbka, która myje twoje ciało. / Żeby skóry gładkiej, miękkiej dotykała. / Rękawiczką co dotyka twojej dłoni. / Co mam zrobić, żebyś bardziej mnie kochała [...]. / Być guziczkiem w klawiaturze telefonu. / Żebyś mogła wezwać mnie i w dzień i nocy. / Chcę pierścionkiem być na twoim palcu mała, / byś mnie ciągle zdejmowała i wkładała.

Jeśli więc w obrębie gatunku pod dekadzie od jego powstania zaczęto puszczać oko do odbiorcy - a może nawet pojawił się tu lekki zwrot ku nowej („bekowej”) publiczności to można zapytać, czy w latach dziewięćdziesiątych w polskim show-biznesie były w ogóle jakiekolwiek zjawiska kampowe. Bo kolory oczywiście były. Jeśli chodzi o ścisły mainstream, to sądzę, że najbliżej kampu był wówczas zespół Blenders (aczkolwiek moim zdaniem plasował się on bliżej „beki”, jeśli już ściśle rozróżniać). Rasowe postaci kampu pojawiały się natomiast w bardzo specyficznej pozycji - na marginesach i w centrum równocześnie. Na marginesach „poważnej” muzyki rozrywkowej i na marginesach wyborów dziennikarzy muzycznych. A przy tym - w centrum pokupności. Zespół Amadeo, założony przez Sławomira Sokołowskiego, twórcę zespołu Bolter, nagrywał muzykę dance, „polski dance” jako odmianę tzw. eurodance, aczkolwiek polski „oficjalny”, głównonurtowy rynek patrzył na muzykę taneczną z obrzydzeniem, wrzucając ją do jednego worka z disco polo ${ }^{23}$. Główna wokalistka Amadeo, Aldona Dąbrowska, była absolwentką policealnego studium piosenkarskiego w Poznaniu i posiadaczką jednego z najlepszych głosów żeńskich w Polsce tamtego czasu. (W nurcie disco polo wówczas - i nadal, choć być może w mniejszym stopniu - panowało przekonanie, że techniczny śpiew nie jest niezbędny do zrobienia kariery). Zespół nagrał całą serię pastiszowych piosenek, jak np. J 23, przeróbkę motywu muzycznego ze Stawki większej niž ṡycie, gdzie męski głos rapował po angielsku: ,J! J! 23 is ok!’24.

23 Sprawy szybko się skomplikowały. O ile w 1995 roku na debiutanckim Dotyku Edyty Górniak występowały wyłącznie piosenki popowe z odrobiną rocka, grane przez żywych muzyków - z wyjątkiem tytułowego utworu, zaprogramowanego na syntezatorach przez kompozytora, Piotra Rubika - co wpisywało się w powszechne w Polsce odczucie, jak powinna brzmieć piosenka pop głównego nurtu, to już na drugim albumie, Edyta (1997) znalazły się piosenki zaaranżowane w konwencji eurodance - Anything i One \& one.

${ }^{24}$ Obraz tego dziełka jest niepełny bez teledysku: https://www.youtube.com/watch?v $=_{\mathrm{O}} \mathrm{kTGSn} 9 \mathrm{VQJk}$ (dostęp: 6.06.2015). Być może jeszcze bardziej kampowy jest telewizyjny występ z wykonaniem tej piosenki. (https://www.youtube.com/watch?v=fYYim0ljcyQ). Studio jest bardzo ubogie, wyglada jak pusty pokój, w którym ustawiono dwie palmy (?), a na podłodze widoczny jest wystający kawałek kabla. Ktoś udaje, że gra na syntezatorze. Wokalistka, której zadaniem jest lipsyncowanie „la la la”, stara się zachować powage, ale w pierwszym wejściu nie zdąża z tekstem, a im dalej w las, tym bardziej jej powaga jest wystawiana na próbę (widać, że chce jej się śmiać, ale się powstrzymuje). Jeden z tancerzy kładzie się na ziemi i usiłuje podskokiem się $\mathrm{z}$ niej podnieść (figura $\mathrm{w}$ break dance), ale trzy razy mu nie wychodzi. Kampowe były też piosenki zrealizowane przez Sokołowskiego wraz z Bohdanem Smoleniem i wokalami Aldony Dąbrowskiej, np. Szalateś szalateś. 
Wyrafinowanym kampem było nowe wcielenie Gaygi jako MC Divy. Ironiczne i dowcipne teksty pisał jej Marcin Lenda, a produkcja muzyczna nie ustępowała standardom zachodniego eurodance (co nie było wówczas w polskiej muzyce oczywistościa). Wokalistka dysponowała kilkuoktawowym głosem, łącznie z sopranem tzw. głowowym, który wykorzystywała w utworach, podobnie jak swoją umiejętność gry na skrzypcach. Trudno wybrać jeden tekst jako ilustrację, ale niech będzie to partia rapowa z piosenki o lecie nad Bałtykiem (U la la z 1996 roku):

\begin{abstract}
$\mathrm{Na}$ piachu rozgrzanym spocone ciała / Obok piwo i cola, nawet gorzała / Trąbisz na alarm kupieckim głosem / Całe wybrzeże teraz jest chaosem / Blady osobnik wychodzi na łowy / Współczynnik szans prawie zerowy / Ostra panienka o brunatnej cerze / Ogląda facetów, myśli o karierze / Żar tak okropny wprowadza w opętanie / Po małym przypaleniu wskazane pływanie.
\end{abstract}

Do największych przebojów MC Divy należała Džiewczyna z. St. Pauli (1995), afirmatywne wyznanie prostytutki („,choć zgubiłam aureolę / nie narzekam, nie narzekam na swą dolę / ja mam życie niebanalne / bo ja żyję niemoralnie”). Teledysk do utworu jest tani, co widać, niemniej kampowy (około czterdziestoletnia wokalistka w różowym futerku występuje na tle zdjęć z zachodnimi sex-shopami oraz gra na skrzypcach elektrycznych w bramie). Piosenka została „odzyskana” na ścieżce dźwiękowej do filmu Yuma Piotra Mularuka (2012) - pojawia się ona w scenie zabawy w dyskotece. Z fragmentów filmu zmontowano nowy teledysk.

\title{
Kamp i hipsteria
}

Podkreślałem w wielu miejscach, że „prawdziwy” kamp - o ile optujemy za utrzymaniem dystynktywności tego pojęcia, a nie uważamy, że jego mutacje i nowe formy mają prowadzić do zrównania tej jakości z innymi poprzez „podobieństwa rodzinne” - wyklucza postawę poważnego wanna be, aspirowania do czegoś wyższego, „dociagania do” (poziomu, bieżącej mody, dominującego stylu w grupie). W domenie interakcji społecznych kamp jest specyficzna pozycją outsiderska, która zakłada świadomość istnienia pewnej wspólnoty smaku, ale opiera się na szukaniu porozumienia z nią nie poprzez jowialny śmiech czy kabaretowy rechot, a poprzez porozumiewawczy uśmieszek i mrugnięcie okiem. W tym 
sensie kamp ustanawia marginalno-elitarną, acz rozproszoną i „donkichotyczną” wspólnotę (w angielszczyźnie funkcjonuje uroczy przymiotnik quixotic), kapryśną i przygodna, co jednak nie oznacza snobizmu. Snob aspiruje do wartości elitarnych, ale takich, które sa powszechnie rozpoznawalne jako wysokie i elitarne. To znaczy, że wartości te są uznawane za takie nie tylko przez „snobów”, a więc przez tych, którzy posiadaja kapitał kulturowy sytuujący ich w grupie „wysokiej”, oraz tych, którzy do takiej grupy aspiruja, ale także przez tych, którzy nie aspiruja do tej grupy, ale mają świadomość, jaki jest „powszechny” dyktat.

Z kampem jest inaczej. Jeżeli coś staje się wartością docenianą powszechnie dla kampu traci wszelki wdzięk, w związku z czym musi się on przemieścić w inną przestrzeń. $\mathrm{Z}$ tej przyczyny zasadne staje się pytanie, czy współczesny dyskurs o hipsterze nie przechwycił mechanizmu kampu. Joanna Filipiak zwróciła uwagę, że kultura się „homoseksualizuje”, przechwytując mechanizmy kampowe: „prawicowi dresiarze” stylizuja się przed wyjściem do klubu, po czym robia sobie zdjęcia, poprawiaja je i publikuja w Internecie. Być może głębokim źródłem tego mechanizmu faktycznie jest kamp. Czy jednak owi dresiarze nie przechwytują mechanizmu hipsterskiego (stylizując się na niedbałych)? Innymi słowy, jeżeli stosuja mechanizm kampu, to jest on zapośredniczony poprzez zjawisko hipsterii. A stąd już niedaleko do nieporozumienia, które jest powszechne we współczesnej kulturze i dotyczy mylenia - lub nakładania się na siebie - pojęć kamp oraz hipsteria.

Chciałbym sięgnąć w głąb archeologii pojęć. Nie każdy kamp gejowski jest postępowy, subwersywny, pisał cytowany wyżej Richard Dyer. Mike Perkovich uzupełniał tę myśl: „Homoseksualna szafa i kamp tym sposobem jednocześnie poręczają za władzę i ją podważają" (2012, 160-161). Mechanizm subwersji, permanentnego ruchu przekraczającego wszystko, co stanie w „centrum”, a zatem przekraczającego także własne założenia, to podstawowy mechanizm queer. $Z$ historycznego punktu widzenia teoria queer jest późniejsza niż kamp, być może więc to teoria queer uogólniła (raczej uogólniła niż przechwyciła, bo „przechwycenie” oznacza przeniesienie do obcego kontekstu, tu zaś konteksty były pokrewne) pewne mechanizmy kampu oraz inne, niekampowe aspekty kultury dysydentów seksualnych i odmieńców. Teoria queer wyzyskała jednak tylko tę „postępową" część kampowych praktyk, w tym sensie mechanizmy kampowe są więc szersze. Analogicznie zatem teoria queer może zajmować się popem, gustem większościowym itd., ale zawsze z nieoczywistego, tj. niedominującego (aktualnie) punktu widzenia. Innymi słowy - kamp i queer stanowia pewien wariant awangardy, tyle że nie jest on ograniczony „do samej estetyczności”, a więc jest „uspołeczniony” i „upolityczniony” (Sobolczyk 2014). Jeżeli uznać ten mechanizm „permanentnej mimikry" za osobliwie ,gejowski”, wypracowany i transportowany przez „kulturę gejowską”, to faktycznie nawiązania do niego można widzieć w kategoriach „homoseksualizacji” kultury. W podobny sposób ponad 30 lat temu Dennis 
Altman pisał o „homoseksualizacji Ameryki”, mając na myśli przede wszystkim obszar mody i obyczajów seksualnych, a w niewielkim stopniu kamp, ponieważ w tamtym czasie „postępowi” geje odwracali się od kampu, zaczął on więc (na moment) funkcjonować jako zjawisko „wsteczne”. Oczywiście kamp miał wpływ na pop i choć jego przenikanie do popu nie zabiło tego „oryginalnego”, tj. marginalnego, krytycznego kampu, to jednak mainstreamowy pseudokamp po prostu w popie się rozpuścił. Faktem jest jednak, że był to przejaw „homoseksualizacji powszechnego smaku”.

W dyskursie o hipsterii pojawia się podobna jak w przypadku kampu idea „prawdziwości”, „oryginalności” i „wyprzedzania”, bycia awangardą (Jaskuła i Jarniewicz 2014, 219). Innymi słowy, klony pozujące na hipsterów nie są nimi „tak naprawdę”, są nimi tylko ci, którzy noszą coś, co w tej chwili nie jest en vogue, a tym samym dowodzą swojego smaku mniejszościowego. Ponieważ wciąż istnieja podmioty kampujące, działające według logiki subwersji, a więc raczej wyprzedzające mody (i niedbające o to, czy je kreuja, bo „prawdziwy” kamper nie jest trendsetterem), zjawiska te moga się ze sobą zlewać, zwłaszcza że aktualnie kategoria hipstera jest dużo bardziej en vogue. Definicyjna frazę tak pojmowanej hipsterii można znaleźć w powieści Nienawiš́ Michała Zygmunta: „Przester był wśród nas najmodniejszy, jak każdy, kto zupełnie nie zwraca uwagi na trendy" (Zygmunt 2014, 6). Wątki dotyczace hipsterii pojawily się w kilku miejscach specjalnego numeru tematycznego Arterii (tylko pozornie odchodzę teraz od Pride, sugeruję jednak, że projektowany czytelnik tego magazynu, tak jak go zrekonstruowałem, to w istocie hipster - i to ten „podrabiany” goniący za modac, a nie ją kreujący - który może asymilować pewne formy kampu, dopóki są „trochę modne, ale jeszcze nie zbanalizowane”). Już sama okładka (autorstwa Agnieszki Kowalskiej-Owczarek) balansuje na granicy hipsterii i kampu jako stylu - na różowym tle przedstawiono głowę mężczyzny z brodą (znak rozpoznawczy hipstera), która tworzy wielki wężowy pierścień, przypominający lisi ogon, wpadający do ust owego mężczyzny (motyw zjadania własnego... ogona). Ewelina Karpowiak w eseju „Estetyczna bylejakość" twierdzi, że estetyka hipsterska czerpie z kampu, po czym sugeruje coś przeciwnego, że to na hipsterię społeczeństwo nakłada dwie kategorie - awangardę i kicz: „Hipster to pluralista, któremu społeczeństwo jednocześnie przypisuje wartości awangardy (zarezerwowanej dla elit intelektualnych) i cechy kiczu" (Karpowiak 2014, 14) ${ }^{25}$. Autorka o tym nie wspomina, ale kategorii tych używa się właśnie w dyskursie o kampie. Czy jednak

${ }^{25}$ W tym samym numerze Natalia Królikowska w eseju o Jerzym Kosińskim jako hipsterze przytacza jednak zupełnie inna genealogię historycznej hipsterii - byli to biali, którzy nosili się jak czarni i imitowali ich styl bycia (definicja Normana Mailera z eseju The White Negro). PRL-owskimi hipsterami byli zapewne „bikiniarze” z Leopoldem Tyrmandem na czele. Z kolei Paulina Ilska w relacji z Festiwalu Sztuk Przyjemnych i Nieprzyjemnych używa metalepsy i zjawisko wcześniejsze przedstawia jako późniejsze. Otóż jej zdaniem hipsterami są Krystian Lupa oraz tandem Strzępka/Demirski, ponieważ są oni „,wariatami” i poszukują tam, gdzie nikt nie poszukuje, a zatem są w awangardzie. Mam wrażenie, że Lupa był w awangardzie jeszcze wtedy, kiedy nie było hipsterii, a tylko awangarda. 
faktycznie media mainstreamowe i potoczna świadomość tak silnie zinterioryzowały kamp, że odruchowo, a przy tym mylnie, nakładaja jego filtry na inne zjawiska? Wątpię. W dodatku autorce zasadnie można postawić zarzut, że sama w istocie robi to, co zarzuca mediom i „potoczności” - jej opis hipsterii to kompilacja tez na temat kampu, częściowo świadoma (bo inspirowana rozpoznaniami Przemysława Czaplińskiego). Z wyjątkiem dość istotnego nieporozumienia: „Kampowy trendsetter powoli przestaje istnieć, ustępując miejsca posłusznemu konsumentowi o guście popularnym” (Karpowiak 2014, 16). Znów mamy tu do czynienia z pomieszaniem ,agencji”. Otóż kamper nie jest i nigdy nie był trendsetterem ani w swoim odczuciu, ani w zamierzeniu. Za takiego (ewentualnie) może go uznać jakaś grupa lub nawet mainstream. Ale on, o ile wciąż jest kamperem, a nie trendsetterem czy biznesmenem, wówczas jest już gdzieś indziej.

\section{Konkluzja}

Opisywana przez Richarda Floridę klasa kreatywna da się zaobserwować także w Polsce, choć w postaci raczkującej i zapewne ograniczonej do kilku wielkich miast - z pewnościa funkcjonuje ona w Warszawie ${ }^{26}$. Jak zasugerowałem w swoim szkicu o kampie

${ }^{26}$ To wynika z pięciu analiz statystycznych polskich województw, dokonanych według modelu „3T” (Technologia, Talent, Tolerancja), zapożyczonego w nieco zmodyfikowanej postaci od Richarda Floridy. Mazowieckie „zwycięża” we wszystkich statystykach (Klincewicz 2012b, 50-54). Wojnar stwierdza, że w Warszawie bardzo duży jest komponent, który Florida nazywa „kreatywnymi specjalistami”, lecz niski pozostaje „superkreatywny rdzeń” - udział artystów i bohemy jest zatem niewielki, w przeciwieństwie do udziału kreatywnych pracowników korporacji. W konkluzji: „specyfiką kreatywności stolicy jest absorbowanie wiedzy z zewnątrz, prawdopodobnie $\mathrm{w}$ wyniku międzynarodowych powiązań korporacyjnych, i stosowanie jej w praktyce w sposób generujący zysk. Jednocześnie stosunkowo niski udział pracowników superkreatywnego rdzenia $(8,2 \%)$ może świadczyć, że zawody typowe dla sektora korporacyjnego wysysaja pracowników z bardziej twórczych zawodów. Może to też znaczyć, że paradoksalnie Warszawa nie wykorzystuje w pełni swojego potencjału kreatywnego w zakresie generowania twórczych pomysłów [...]. W konsekwencji być może osoby kreatywne, które mogłyby pracować w zawodach bardziej innowacyjnych (np. przedsiębiorstwach typu start-up), wykonuja zadania rutynowe, ponieważ sektor korporacyjnoadministracyjny oferuje im bardziej stabilne zatrudnienie i wyższe dochody" (Wojnar 2016, 99-102). Dodałbym, że dzieje się tak prawdopodobnie wskutek założenia przyjętego zarówno przez międzynarodowe korporacje, jak i przez pewien rodzaj „skolonizowanej świadomości” w Polsce, a mianowicie, że twórcze pomysły generowane sa na mitycznym Zachodzie, w Polsce zaś wystarczy je kopiować. Powyższy opis dotyczy zresztą nie tylko usytuowania klasy kreatywnej w Warszawie, ale w Polsce w ogóle. O podobnym zjawisku, które nazwane jest, moim zdaniem nietrafnie, „twórcza imitacja”" (proponowałbym raczej „imitację tego, co twórcze”), pisze Wojnar (Wojnar 2016, 271). Od dość dawna zjawisko to można obserwować na przykładzie rynku reklam. Swego czas w polskich stacjach telewizyjnych emitowano długie bloki - niczym zbiory tzw. szortów, czyli filmów krótkometrażowych - ,zakazanych reklam”. Były to zagraniczne reklamy produktów nierzadko dostępnych także w Polsce, jednak na nasz rynek przygotowywano bądź adaptowano reklamy „bezpieczne” (część tych spotów nie trafiała do emisji również na Zachodzie, pojawiała się natomiast w Internecie). Popularność bloków „zakazanych reklam” dowodzi, że określona nisza, być może zorganizowana wedle mechanizmu „beki”, reklamy „niegrzeczne” docenia. Zapewne jest to jednak nisza bliższa 
środkowoeuropejskim w prozie Michała Witkowskiego, być może Polska „padła ofiara” pewnego wmówienia, przyjmując za właściwy model ekonomiczny kapitalizm neoliberalny w momencie, kiedy dojrzałe gospodarki kapitalistyczne dostrzegały już ograniczona wydolność tego modelu i szukały alternatyw (jedną z nich jest właśnie rozwój klasy kreatywnej). Krótko mówiąc - choć to materiał na obszerne rozprawy - dominująca kultura w Polsce zaprzecza modelowi kreatywnemu z powodu faworyzowania jednego „," (technologii) 27 i niedoceniania innego „t” (tolerancji) ${ }^{28}$, a to właśnie taki zintegrowany model, co Richard Florida popiera statystykami, przynosi długofalowy sukces ekonomiczny. Miasta, które stawiają na rozwój usług, nie przestawiają się zaś na etos kreatywności, stają się głównie siedzibami call centers, a nie kreatywnymi przestrzeniami dla innowacyjnych start-upów, nie mówiąc już o kulturze. Dotyczy to także gospodarek tych krajów, które swój główny atut widzą w tym, że oferują tzw. „tanią a wykwalifikowaną siłę roboczą” (Wojnar 2016, 188). Uważam, że do takiego etosu - etosu „dorabiania się” - odwołuje się magazyn Pride29.

publiczności festiwalu filmowego Nowe Horyzonty, aniżeli widzom cinepleksu popkornowego, a prawdopodobnie tylko taki adres uznaje się za wart inwestycji w reklamę. Notabene w owych „zakazanych reklamach" zdarzało się twórcze wyzyskanie kampu.

${ }^{27} \mathrm{~W}$ dużym uproszczeniu można by powiedzieć, że w Polsce wciąż przyjmuje się za oczywistość podział na bohemian i bourgeois oraz premiuje się ten drugi biegun, pierwszy zaś releguje się do sfery prekariatu. Kuba Szreder rozróżnia „prekariat” od „projektariatu” na gruncie teoretycznym (duża część projektariuszy funkcjonuje $\mathrm{w}$ ten sposób $\mathrm{z}$ wyboru, prekariusze $-\mathrm{z}$ przymusu), ale $\mathrm{w}$ polskiej praktyce kondycje te mieszaja się: „Możemy sobie wyobrazić, jak dobrze pracować nad projektem 2-3 letnim, na który dostajemy przyzwoite pieniądze, zajmujemy się czymś ciekawym, współpracujemy z grupą ludzi, których sami sobie dobieramy. Taka sytuacja jest idealna, ale rzadko się zdarza. W rzeczywistości freelancer robi 5-6 projektów jednocześnie, bo pojedyncze nie są tak długotrwałe i dobrze płatne, żeby móc się z nich utrzymać. Musi myśleć nie tylko o tym, czym zajmuje się w danym momencie, ale co będzie za pół roku, czy rok. Dlatego w międzyczasie ubiega się o kilka, a nawet kilkanaście projektów i nigdy nie wie, czy i na który dostanie pieniądze. Każde aplikowanie wiąże się z konkurowaniem z dużą liczbą osób, które również są bolidami krążącymi pomiędzy projektami. Ta gra rozgrywa się między konwencją proletariatu, prekariatu i entuzjazmu" (Szreder i Stelmach 2016). Szreder jest kuratorem sztuki.

28 Badanie „luk kreatywności” w Polsce wykazało, że największa, zasadnicza luka występuje właśnie w zakresie trzeciego „t”, tolerancji (Miedzianowska 2012, 166-167). W klasyfikacji modeli konceptualnych kreatywności Carla Grodacha polska kultura podpada pod „model konwencjonalny”, w którym wspiera się wyłącznie czynniki ekonomiczne, tzw. „twarde czynniki”, wyraźnie rozdzielając je od kultury („czynników miękkich”). Modele Grodacha przytacza Wojnar (Wojnar 2016, 30-31). Inne rozróżnienie, użyte przez Floridę w tekście nietłumaczonym na polski, to business climate vs people's climate jako priorytety w zarządzaniu (model kreatywny zakłada, że people's climate sprzyja kreatywności, a tym samym i rozwojowi ekonomicznemu). Polski model to ewidentnie business climate (Wojnar 2016, 71). Nie przypadkiem przecież niedawno w Polsce odbywały się manifestacje pod hasłem „Dziady Kultury” (od „dziadowskich” płac w tym sektorze).

${ }^{29}$ Ponadto problem w badaniach nad polską klasą kreatywną dotyczy trzeciego „t”" (tj. Tolerancji), zwiazzany jest z Gay Index i homoseksualnością w ogóle. Kiedy Krzysztof Klincewicz omawia koncepcję Floridy i Indeks Tolerancji, pisze o akceptacji odmiennych stylów życia, mniejszości narodowych i religijnych - a pomija zupełnie tolerancję wobec osób LGBT, jak gdyby milcząco zakładając, że ta mieści się w kategorii „odmienne style życia” (Klincewicz 2012a, 10). W cytowanych badaniach statystycznych „Technologia, talent i tolerancja w polskich województwach" ten sam badacz stwierdza, że koncepcja tolerancji oparta tylko na Wskaźniku Liczby Gejów była zbyt uproszczona. W seriach danych dotyczących tolerancji próbuje jednak stworzyć polski odpowiednik Gay Index. Problem polega bowiem na tym, że polskie badania demograficzne i statystyczne nie obejmowały jak dotąd kategorii homoseksualności. Klincewicz i jego współpracownicy znaleźli sprytny sposób, by takiego pomiaru dokonać - przebadali liczbę ogłoszeń towarzyskich homoseksualistów na 1000 
Powoływanie się na siłę ,gejowskiego pieniądza” (zdobędziecie kapitał społeczny, jeśli zdobędziecie kapitał ekonomiczny) wyraźnie przeczy temu, o czym pisze Florida, a co można parafrazować następująco: zdobędziecie kapitał społeczny, jeśli wyzyskacie wasz potencjał kreatywny. Ponadto w neoliberalnym modelu próby łączenia alternatywnych stylów życia z dominującymi trendami ekonomicznymi mają wszelkie znamiona „utowarowienia fajności” [commodification of cool], czyli „wrogiego przejęcia”, wyciskającego off jak cytrynę tak długo, jak długo da się na nim zarobić, co w „klasie kreatywnej”, jak zwracałem uwagę, nie dokonuje się już tak łatwo ${ }^{30}$. Z powyższych powodów twierdzę, że na obecną chwilę do opisu polskiej kultury konieczne jest zachowanie choćby okrojonej dystynktywności kampu, ponieważ nie stał się on stylem ponadmniejszościowym. Tu skądinąd kamp okazuje się estetyką wręcz „modelowa”, jako że jego relacja z popem już w latach sześćdziesiątych była nad wyraz skomplikowana (kamp przetwarzał pop i kulturowe „śmieci”, jednocześnie nie będąc popem) (Ross 2012, 342-345) ${ }^{31}$. Co więcej, jak zwraca uwagę Andrew Ross, historyczny kamp nie

mieszkańców miast na podstawie serwisu internetowego Gejowo.pl. Tę samą metodę wykorzystała Katarzyna Wojnar (Wojnar 2016, 94). Jest to jednak pomysł dyskusyjny, jako że uzyskane w ten sposób wyniki mogą być mylące. Po pierwsze, już pobieżne przejrzenie anonsów na stronie Gejowo.pl, gdzie ogłoszenia przedstawione są na mapce Polski, prowadzi do wniosków, że im większa stolica regionu, tym więcej ogłoszeń, co nie problematyzuje zagadnienia tolerancyjności danego dużego miasta (hipotetycznie: duży Białystok może być mniej tolerancyjny niż podobna liczebnie Bydgoszcz). Po drugie, Gejowo.pl zamieszcza różne rodzaje ogłoszeń i nie wiadomo, co badający uznali za „ogłoszenia towarzyskie” - czy (statystycznie najliczniejsza) kategorię „sex”, czy „szukam partnera”, czy „szukam przyjaciela”, czy może np. „praca”, „inne” bądź „widziałem cię”. Ponadto jeden użytkownik może dodać ogłoszenia we wszystkich kategoriach równocześnie, a nawet w tej samej kategorii, zmieniając pseudonim lub nie; w dodatku część użytkowników, aby poprawić widoczność (pozycjonowanie) swojego anonsu, publikuje go ponownie, mimo że poprzedni nadal jest widoczny. Po trzecie, można argumentować, że liczba ogłoszeń zupełnie nie musi korelować z poziomem tolerancji miasta, ponieważ w miejscowości, gdzie nie ma „sceny gejowskiej”, tj. pubów czy dyskotek bądź organizacji LGBT, w których (hipotetycznie) można zawrzeć znajomość, liczba ogłoszeń może być wyższa, jako że strona internetowa staje się wówczas głównym medium społeczności. Po czwarte - co najbardziej skomplikowane i przeto być może dyskusyjne - anonse na Gejowo.pl być może apelują tylko do określonej części środowiska gejowskiego w Polsce, ponieważ ich konstrukcja jest otwarta i nie wymaga załączenia zdjęcia ani podania „drażliwych danych", takich jak wiek, co nie zawsze jest regułą w portalach bądź aplikacjach typu Fellow.pl, Kumpello czy Grindr (nawet jeśli ktoś zamieszcza zdjęcie krajobrazu bądź nie zamieszcza żadnego, a wiek określa jako „96”, to znaczna część użytkowników z zasady ignoruje profile bez fotografii, nierzadko zaznaczając to w swoich opisach profilowych); w konsekwencji być może (to hipoteza) Gejowo.pl częściej wybierają osoby ze starszego pokolenia, ale też te o niskim stopniu ujawnienia, czyli żyjące w szafie - to zaś wskazuje na coś odwrotnego niż „wysoki poziom tolerancji”. Štěpán Pořízek (autor pracy dyplomowej o anonsach gejowskich) zgodził się ze mna, dodając, że anonse towarzyskie na Gejowo.pl najbardziej przypominają dawniejsze czy „tradycyjne” formy ogłoszeń towarzyskich, tj. ogłoszenia prasowe, i z tego powodu mogą być preferowane albo przez osoby starsze, albo mniej zainteresowane innowacyjnymi formami komunikacji.

30 Innymi słowy, nie chodzi o „modernistyczny” opór „prawdziwych twórców” przed rynkiem w duchu drugiej połowy dziewiętnastego wieku, praktykowany przez Baudelaire’a czy Flauberta, jak zapewne widzieliby to Adorno i Horkheimer, ale o zmianę modelu ekonomicznego na taki, który nie będzie relacją jednostronnie definiowana przez korporacje czy neoliberalnych zarządców.

${ }^{31}$ Jeśli więc przywołać ponownie oś utowarowienie kultury-wpisanie treści symbolicznych w produkcję towarowa, pop „klasyczny” odpowiadałby temu pierwszemu biegunowi, kamp zaś byłby bliższy temu drugiemu, ale jako reakcja na pierwszy. Próbuję rozróżnić „pop klasyczny” od innej jego postaci, ponieważ uważam, że współcześnie - prawdopodobnie wskutek konwergencji z nową klasą kreatywną - pop bardzo się zniuansował i wytworzył wiele ścieżek czy wręcz nisz w mainstreamie, w czym niejako zbliżył się do kampu. 
widział siebie jako kontrkultury (choć tak był postrzegany z zewnątrz), a postulował raczej ironiczno-krytyczną mimikrę istniejących form kulturowych (Ross 2012, 356). Łączył zatem impulsy „trwania” czy „afirmacji” oraz „zerwania” bądź „kontestacji”; powiedzmy: obydwa „bo-”.. 


\section{Wykaz literatury}

„Jak nas gay ikona Helena Vondrackova...”. 2014. http://boyler.cz/jak-nas-gay-ikonahelena-vondrackova-nemile-prekvapila-gay-rodiny-nesouhlasim-je-to-anomalie/

Altman, Denis. 1982. The Homosexualization of America. Boston: Beacon Press.

Brooks, David. 2001. Bobos in Paradise. The New Upper Class and How They Got There. New York: Simon \& Schuster.

Chilewicz, Patryk. 2014. „Walka o tron”. Pride 1: 78-85.

Core, Philip. 1984. Camp. The Lie that Tells the Truth. London: Plexus.

Core, Philip. 2012. „Kampowe reguły”. Tłum. K. Hoffmann. W Kamp. Antologia przekładów. Red. P. Czapliński, A. Mizerka. Kraków: Universitas.

Dyer, Richard. 2012. „O kampowaniu, które trzyma nas przy życiu”. Tłum. B. Komisarek. W Kamp. Antologia przełeładów. Red. P. Czapliński, A. Mizerka. Kraków: Universitas.

Filipiak, Joanna. 2015. „Z tęczową soczewką w oku”. Pride 3: 79-81.

Florida, Richard. 2010. Narodziny klasy kreatymnej. Tłum. T. Krzyżanowski, M. Penkala. Warszawa: Narodowe Centrum Kultury.

Frank, Thomas. 1997. The Conquest of Cool. Business Culture, Counterculture, and the Rise of Hip Consumerism. Chicago: University of Chicago Press.

Jameson, Fredric. 2011. Postmoderniż, czyli logika kulturowa późnego kapitaližmu. Tłum. M. Płaza. Kraków: Wydawnictwo Uniwersytetu Jagiellońskiego.

Jaskuła, Zdzisław i Jerzy Jarniewicz. 2014. „Gesty hipsterskie i gesty lanserskie”. Arterie 1 (18): 216-222.

Justynasteczkowska.pl. https://justynasteczkowska.pl/letmeknow/page/167/

Karpowiak, Ewelina. 2014. „Estetyczna bylejakość”. Arterie 1 (18): 14-19.

Kleinhans, Chuck. 2012. „Wyjmowane z kosza. Kamp i polityka parodii”. Tłum.

K. Szewczyk. W Kamp. Antologia pržekładón. Red. P. Czapliński, A. Mizerka. Kraków: Universitas.

Klincewicz, Krzysztof. 2012. „Koncepcja klasy kreatywnej Richarda Floridy i klasa kreatywna w Polsce". W Klasa kreatywna w Polsce. Technologia, talent i tolerancja jako źródła rozpwoju regionalnego. Red. K. Klincewicz. Warszawa: Wydawnictwo Naukowe Wydziału Zarządzania UW.

Klincewicz, Krzysztof. 2012. „Technologia, talent i tolerancja w polskich województwach”. W Klasa kreatywna w Polsce. Technologia, talent i tolerancja jako źródła roz̨woju regionalnego, red.

K. Klincewicz. Warszawa: Wydawnictwo Naukowe Wydziału Zarządzania UW.

Kupka, Tomasz. 2015a. „Chłopcy z krainy Oz”. Pride 2: 106-109.

Kupka, Tomasz. 201b. „Guilty Pleasures”. Pride 3: 110-111.

Medhurst, Andy. 2012. „Kamp”. Tłum. P. Czapliński. W Kamp. Antologia præekładów. Red. P. Czapliński, A. Mizerka. Kraków: Universitas.

Miedzianowska, Magdalena. 2012. „Klasa kreatywna a fundusze unijne”. W Klasa kreatywna w Polsce. Technologia, talent i tolerancja jako źródła rozwoju regionalnego. Red. K. Klincewicz.

Warszawa: Wydawnictwo Naukowe Wydziału Zarządzania UW.

Miller, Maciek. 2005. Pozytywni. Kraków: Korporacja Ha!Art.

Ostrowska, Małgorzata i Przemysław Górecki. 2016. „Wzajemnie się wyczuwamy. Z

Małgorzatą Ostrowską rozmawia Przemysław Górecki”. Replika 59: 10-11.

Perkovich, Mike. 2012. „Michaśki, kamp, cioty i literatura amerykańska”. Tłum. J. Połtyn. W Kamp. Antologia przekłtadów. Red. P. Czapliński, A. Mizerka. Kraków: Universitas.

Pride. 2015, 2.

Pride. 2015, 3.

Replika. 2015, 56. 
Robertson, Pamela. 2012. „Jak jest zrobiony feministyczny kamp?”. Tłum. P. Sobolczyk. Teksty Drugie 5: 103-126.

Ross, Andrew. 2012. „Kamp: sposoby użycia”. Tłum. E. Rajewska. W Kamp. Antologia przekładów. Red. P. Czapliński, A. Mizerka. Kraków: Universitas.

Sobolczyk, Piotr. 2014. „The Anxiety of (Social) Influence”. Praktyka Teoretyczna 1: 25-52.

Sobolczyk, Piotr. 2015. „Central European Communist Camp”. W New Approaches to Gender and Queer Research in Slavonic Studies. Red. D. Scheller-Boltz. Wiesbaden: Verlag Harrasowitz.

Sontag, Susan. 2012. „Notatki o kampie”. Tłum. W. Wertenstein. W Kamp. Antologia pržekładów. Red. P. Czapliński, A. Mizerka. Kraków: Universitas.

Szreder, Kuba i Monika Stelmach. 2016. „Nieustające wakacje. Z Kubą Szrederem rozmawia Monika Stelmach". dwutygodnik.com 190. http:/ /www.dwutygodnik.com/artykul/6659nieustajace-wakacje.html (dostęp: 08.01. 2017).

Vondráčkova, Helena i Paweł Piotrowicz. 2013. „Chopin, geje i ostrygi”. https://kultura.onet.pl/muzyka/gatunki/pop/chopin-geje-i-ostrygi/nlywjjb (dostęp: 19.06.2018).

Wojnar, Katarzyna. 2016. Polska klasa kreatywna. Warszawa: Narodowe Centrum Kultury.

Wróblewski, Sergiusz i Przemysław Górecki. 2015. „Nie dla mnie kapcie i kanapa. Z Sergiuszem Wróblewskim rozmawia Przemysław Górecki”. Replika 56: 30.

Zygmunt, Michał. 2014. Nienawiść. Warszawa: Wydawnictwo Krytyki Politycznej. 
Piotr Sobolczyk - dr, pracuje w Instytucie Badań Literackich PAN, autor książek Tadeusz̧a Micińskiego podróż do Hiszpanii (2005), Dyskursywizowanie Białoszewskiego (t. I 2013, t. II 2014), Queerowe subwersje. Polska literatura homotekstualna i zmiana spotecæna (2015), Polish Queer Modernism (2015), Gotycyzm - modernistyczny sobowtór odmieńca (2017). W 2018 roku ukaże się The Worldview - the Trope - and the Critic (angielski przekład I tomu Dyskursymizowania Białoszenskiego). Stypendysta Fundacji Estreicherów (2005), Prezydenta Miasta Krakowa (2005), Fundacji na rzecz Nauki Polskiej (2008 i 2009), Ministra Kultury i Dziedzictwa Narodowego (2011), otrzymał również stypendium dla młodych wybitnych naukowców (2015-2018). Kierownik grantu NCN (2012-2015). Gościnny wykładowca na Uniwersytecie Jagiellońskim, Universitat i Oslo, INALCO, Universidad Pablo de Olavide. Aktualnie w ramach grantu NPRH przygotowuje polski przekład traktatu o konceptyzmie Baltasara Graciana oraz autorską antologię hiszpańskiej poezji siglo de oro.

\section{DANE ADRESOWE:}

Instytut Badań Literackich PAN

ul. Nowy Świat 72

00-330 Warszawa

EMAIL: psobolczyk@wp.pl

CYTOWANIE: Sobolczyk Piotr. 2018. „Nowe formy kampu, nowa klasa kreatywna i wynikające stąd nieporozumienia" Praktyka Teoretycz̧na 2(28): 192-219.

DOI: $10.14746 /$ prt.2018.2.10

\section{AUTHOR: Piotr Sobolczyk}

TITLE: New forms in Camp and the Resulting Misunderstandings

ABSTRACT: The text analyses how the relation of contemporary Polish gay culture to camp is changing, and how these changes are related to new phenomena in pop culture. Furthermore, the author discusses whether similar (camp) taste and similar (camp) lifestyle allow us to understand queer community as the "new creative class" according to Richard Florida. Among the phenomena discussed are "gay diva worship", "guilty pleasures", "hoot" and "hipster". The material analysed comes from the Polish LGBTQ press.

KEYWORDS: camp, gay culture, new creative class, LGBTQ press, pop. 